УДК $577.2+575.2+571.27+617.7$

\author{
A.M. KUCHERENKO ${ }^{1,2}{ }^{\text {, V.M. PAMPUKHA }}{ }^{1}$, G.I. DROZHZHYNA ${ }^{3}$, L.A. LIVSHITS ${ }^{1}$ \\ ${ }^{1}$ Institute of Molecular Biology and Genetics of the National Academy of Sciences of Ukraine, Kyiv \\ E-mail: kucherenko.a.m@gmail.com \\ 2 Taras Shevchenko National University of Kyiv, Educational and Scientific Centre «Institute of Biology» \\ ${ }^{3} \mathrm{SI}$ «The Filatov Institute of Eye Diseases and Tissue Therapy, AMS of Ukraine», Odesa
}

\title{
IL1 $\beta$, IL6 AND IL8 GENE POLYMORPHISMS INVOLVEMENT IN RECURRENT CORNEAL EROSION IN PATIENTS WITH HEREDITARY STROMAL CORNEAL DYSTROPHIES
}

TGFBI gene mutations cause corneal stromal dystrophies of autosomal dominant inheritance. The most frequent complication of stromal dystrophies is recurrent corneal erosion with varying degree of accompanying inflammation. $I L-1 \beta$, $I L-6$ and $I L-8$ are main cytokines involved in corneal erosion healing. This study aimed to investigate the association between IL1B gene $-511 \mathrm{C} / \mathrm{T}$, IL6 gene $-174 \mathrm{G} / \mathrm{C}$ and IL8 gene $-781 C / T$ polymorphisms and risk of recurrent erosion development in patients with hereditary corneal stromal dystrophies. A trend to decrease of IL1B gene -511TT genotype frequency in group with erosion (3,7\%) comparing to control $(6,7 \%)$ was observed. IL6 gene $-174 \mathrm{C}$ allele carriers frequency in control group $(65,9 \%)$ was significantly $(P<$ $<0,05)$ lower comparing to patients with erosion $(80,5 \%)$. Frequency of IL8 -781TT genotype was significantly $(P<$ $<0,05)$ lower in the group with erosion $(10,7 \%)$ comparing to patients without erosion (30,8\%) and control (25\%). IL6 gene $-174 C$ allele may be considered as genetic marker of corneal erosion risk in patients with hereditary stromal corneal dystrophies, whereas IL8 -781TT genotype is associated with negative recurrent erosion prognosis in such patients.

Introduction. Corneal dystrophies are a clinically and genetically heterogeneous group of hereditary conditions characterized by the progressive accumulation of deposits in different layers of the cornea, with resulting loss of refractive index and transparency [1, 2]. Most corneal stromal dystrophies are inherited as autosomal dominant traits with great intrafamiliar and interfamiliar variation of clinical expressivity and high degree of penetrance [3]. The lattice corneal dystrophy (LCD) is the most common corneal stromal dystrophy type in Ukraine. Its frequency among others is $40,2 \%$. LCD type I and type IIIA have been reported to be caused by specific point mutations in the TGFBI (transforming growth factor beta-induced) gene and to have autosomal dominant inheritance pattern. The main mutations associated with LCD in Ukrainian patients are Hys626Arg (type IIIA) and

(C) A.M. KUCHERENKO, V.M. PAMPUKHA, G.I. DROZHZHYNA, L.A. LIVSHITS, 2013
Arg124Cys (type I) in TGFBI gene with respective frequencies of 0,416 and 0,375 [4]. Accumulation deposits accumulation in patients with hereditary stromal corneal dystrophies (HSCD) leads to impaired attachment of epitheliocytes to basement membrane - corneal erosion. Presence of recurrent corneal erosions is characteristic of LCD type I and type IIIA and is the primary reason for consulting ophthalmologist. The clinical findings showed that frequency, intensity and degree of corneal inflammatory reactions significantly differ in various patients [5]. It is supposed that the degree of inflammation caused by corneal erosion in LCD patients is under control of modifier genes. In particular, genes coding pro- and anti-inflammatory cytokines are the possible candidates to influence corneal woundinduced erosion [6].

Two main acute inflammation phase cytokine genes $I L I B$ and $I L 6$ as well as major chemoattraction cytokine gene $I L 8$ are expressed in injured corneal epithelium [7]. Proteins which are encoded by these genes are found in the tear of injured corneal tissue and play crucial role in corneal wound healing [8]. Experiments on mice model demonstrated that polymorphisms of cytokine genes can significantly affect the level and functional activity of encoded proteins [9]. Furthermore, it was shown that polymorphic variants of cytokine genes can significantly modify features of different diseases (arthritis, asthma, etc.) [10, 11]. IL $1 B$ gene -511 $\mathrm{C} / \mathrm{T}$, IL6 gene $-174 \mathrm{G} / \mathrm{C}$ and IL 8 gene $-781 \mathrm{C} / \mathrm{T}$ variants influence these genes expression in epithelium and thus have been selected for this study.

Purpose - to investigate possible involvement of IL $1 B$ gene $-511 \mathrm{C} / \mathrm{T}$, IL 6 gene $-174 \mathrm{G} / \mathrm{C}$ and IL 8 gene $-781 \mathrm{C} / \mathrm{T}$ polymorphisms in corneal erosion development in patients with LCD.

Materials and methods. Case group consisted of 69 patients with lattice corneal dystrophy type I $(n=$

ISSN 0564-3783. Цитология и генетика. 2013. T. 47. № 3 
$=46)$ and type IIIA $(n=23)$ with confirmed presence of TGFBI gene Arg124Cys and Hys626Arg mutations respectively. All patients included in this research had aseptic corneal inflammation. This group consisted of 56 individuals with recurrent erosion history and 13 ones - without it. The control group comprised healthy individuals $(n=105)$ from Ukraine without familial HSCD history. All individuals were involved in the investigation after giving informed consent.

DNA was extracted from peripheral blood leukocytes of the patients with lattice corneal dystrophy type I and IIIA and healthy individuals according to the standard procedures. Genotyping for Arg124Cys, Hys626Arg mutations of the TGFBI gene, ILIB gene $-511 \mathrm{C} / \mathrm{T}$, IL6 gene $-174 \mathrm{G} / \mathrm{C}$ and IL8 gene $-781 \mathrm{C} /$ $\mathrm{T}$ polymorphisms was performed by the PCR with following restriction fragment length polymorphism (RFLP) analysis as described elsewhere [11-13]. Statistical analysis has been performed using GenePop and OpenEpi statistical packages [14, 15]. A P-value of less than 0.05 was taken as significant.

Results. The observed genotype distributions for three polymorphic variants showed no deviation from the ones expected according to Hardy-Weinberg equilibrium in all investigated groups (Table).

No significant differences in $I L 1 B$ gene $-511 \mathrm{C} / \mathrm{T}$ genotype or allelic frequencies between patients with erosion and without it were found. Whereas a trend to decrease of -511 TT genotype frequency in group with erosion $(3,7 \%)$ comparing to control $(6,7 \%)$ was observed. Frequency of IL6 gene $-174 \mathrm{C}$ allele carriers was higher in the group with recurrent erosion $(80,5 \%)$ comparing to the group without erosion (60\%). The difference was statistically insignificant, though. However, $-174 \mathrm{C}$ allele carriers frequency in control group $(65,9 \%)$ was significantly $(\mathrm{P}<0,05)$ lower comparing to the patients with erosion $(80,5 \%)$. Frequency of IL $8-781$ TT genotype was significantly $(\mathrm{P}<0,05)$ lower in the group with erosion $(10,7 \%)$ comparing to the patients without erosion $(30,8 \%)$ and control (25\%).

Discussion. Our results revealed possible involvement of $I L 1 B$ gene $-511 \mathrm{C} / \mathrm{T}$, IL6 gene $-174 \mathrm{G} / \mathrm{C}$ and $I L 8$ gene $-781 \mathrm{C} / \mathrm{T}$ polymorphisms in inflammatory reaction development leading to corneal erosion. Obtained data are corroborated by existing knowledge about corneal wound healing process in general and recurrent erosion development in par- ticular. Corneal epitheliocytes death in vivo initiates a strong inflammatory response. Necrotic cells release so called «danger» signals (interferon- $\alpha$, heat shock proteins, etc.) triggering inflammation in tissue [16]. These «danger» molecules enhance production of IL-1 $\beta$, IL- 6 and IL-8 stimulating inflammatory cells recruitment, corneal epitheliocytes migration and neovascularization crucial for injured cornea healing [17]. IL1B -511 T, IL6 gene $-174 \mathrm{G}$ and $I L 8-781 \mathrm{~T}$ alleles are associated with increased levels of corresponding interleukins $[18,19]$. Recurrent corneal erosion is self-inducing process due to described above «danger» molecules action. Though inflammation is necessary for corneal healing, excessive inflammation is damaging. It induces corneal ulceration and melting. Increased levels of pro-inflammatory interleukins may prevent recurrent corneal erosion development through recruitment of monocytes and following clearance of damaged or necrotic cells. Quick phagocytosis of necrosis products might possibly attenuate self-induction mechanism of corneal erosion spreading thus decreasing risk of its development.

\section{Genotype frequency}

for studied polymorphic variants, $n(\%)$

\begin{tabular}{l|c|c|c}
\hline Genotype & $\begin{array}{c}\text { Patients } \\
\text { with recurrent } \\
\text { corneal } \\
\text { erosion }\end{array}$ & $\begin{array}{c}\text { Patients } \\
\text { without } \\
\text { corneal } \\
\text { erosion }\end{array}$ & $\begin{array}{c}\text { Control } \\
\text { group, } n(\%)\end{array}$ \\
\hline \multicolumn{4}{c}{$-511 \mathrm{C} / \mathrm{T}$ IL 1B gene } \\
Total* & 54 & 13 & 105 \\
CC & $22(40,7)$ & $2(15,4)$ & $51(48,6)$ \\
CT & $30(55,6)$ & $11(84,6)$ & $47(44,8)$ \\
TT & $2(3,7)$ & $0(0)$ & $7(6,7)$ \\
\multicolumn{5}{c}{} & $-781 \mathrm{C} / \mathrm{T}$ IL 8 gene & \\
Total* & 56 & 13 & 100 \\
CC & $18(32,1)$ & $3(23,1)$ & $30(30)$ \\
CT & $32(57,2)$ & $6(46,2)$ & $45(45)$ \\
TT & $6(10,7)$ & $4(30,8)$ & $25(25)$ \\
\multicolumn{5}{c}{} & $-174 \mathrm{G} / \mathrm{C}$ IL6 gene & \\
Total* & 41 & 10 & 88 \\
GG & $8(19,5)$ & $4(40,0)$ & $30(34,1)$ \\
GC & $25(61,0)$ & $4(40,0)$ & $39(44,3)$ \\
CC & $8(19,5)$ & $2(20,0)$ & $19(21,6)$ \\
\hline
\end{tabular}

* Total number of individuals genotyped for a polymorphic variant. 
Conclusion. Possible role of $I L 1 B$ gene $-511 \mathrm{C} / \mathrm{T}$, IL6 gene $-174 \mathrm{G} / \mathrm{C}$ and $I L 8$ gene $-781 \mathrm{C} / \mathrm{T}$ polymorphisms as modifiers of recurrent corneal erosion development risk in patients with hereditary corneal stromal dystrophies was established. IL6 gene $-174 \mathrm{C}$ allele may be considered as genetic marker of corneal erosion risk in patients with LCD, whereas $I L 8-781 \mathrm{TT}$ genotype is associated with negative recurrent erosion prognosis in such patients.

А.М. Кучеренко, В.Н. Пампуха,

Г.И. Дрожжжина, Л.А. Лившии,

ВОВЛЕЧЕНИЕ ПОЛИМОРФИЗМОВ

ГЕНОВ IL 1B, IL6 И IL8 В РАЗВИТИЕ РЕЦИДИВИРУЮЩИХ ЭРОЗИЙ У ПАЦИЕНТОВ С НАСЛЕДСТВЕННЫМИ ДИСТРОФИЯМИ СТРОМЫ РОГОВИЦЫ

Мутации в гене TGFBI обусловливают группу стромальных дистрофий роговицы аутосомно-доминантного типа наследования. Самым распространенным осложнением стромальных дистрофий являются рецидивирующие эрозии, отличающиеся степенью сопутствующего воспаления. IL-1 $\beta$, IL-6 и IL-8 - основные цитокины, вовлеченные в заживление эрозий роговицы. Целью настоящей работы было изучить ассоциацию между полиморфизмами $-511 \mathrm{C} / \mathrm{T}$ гена $I L 1 B,-174 \mathrm{G} / \mathrm{C}$ гена $I L 6$ и $-781 \mathrm{C} / \mathrm{T}$ гена $I L 8$ и риском развития рецидивирующих эрозий у пациентов с наследственными стромальными дистрофиями роговицы. Наблюдалась тенденция к повышению частоты генотипа -511 TT гена $I L 1 B$ в группе пациентов с эрозиями $(3,7 \%)$ по сравнению с контролем $(6,7 \%)$. Частота носителей аллеля $-174 \mathrm{C}$ гена IL6 в контрольной группе $(65,9 \%)$ была достоверно $(\mathrm{P}<0,05)$ ниже по сравнению с группой пациентов с эрозиями $(80,5 \%)$. Частота генотипа -781 TТ гена $I L 8$ была достоверно $(\mathrm{P}<0,05)$ ниже в группе пациентов с эрозиями $(10,7 \%)$ по сравнению с группой пациентов без эрозий $(30,8 \%)$ и контролем (25\%). Аллель $-174 \mathrm{C}$ гена IL6 может рассматриваться как генетический маркер риска развития эрозий роговицы у пациентов с наследственными стромальными дистрофиями роговицы, в то же время генотип -781ТT гена ILS, наоборот, ассоциирован с негативным прогнозом развития эрозий у таких пациентов.

А.М. Кучеренко, В.М. Пампуха,

Г.І. Дрожжина, Л.А. Лівшиць

ЗАЛУЧЕННЯ ПОЛІМОРФІЗМІВ ГЕНІВ IL $1 B$, IL6 ТА IL 8 ДО РОЗВИТКУ РЕЦИДИВУЮЧИХ ЕРОЗІЙ У ПАЦІЕНТІВ ЗІ СПАДКОВИМИ ДИСТРОФІЯМИ СТРОМИ РОГІВКИ

Мутації в гені $T G F B I$ зумовлюють групу стромальних дистрофій рогівки з аутосомно-домінантним типом успадкування. Найпоширенішим ускладненням стро- мальних дистрофій є рецидивуючі ерозії, які відрізняються за ступенем супутнього запалення. IL$1 \beta$, IL-6 та IL-8 - основні цитокіни, залучені до загоєння ерозій рогівки. Метою цієї роботи було дослідити асоціацію між поліморфізмами $-511 \mathrm{C} / \mathrm{T}$ гена $I L 1 B,-174 \mathrm{G} / \mathrm{C}$ гена $I L 6 \mathrm{i}-781 \mathrm{C} / \mathrm{T}$ гена $I L 8$ та ризиком розвитку рецидивуючих ерозій у пацієнтів зі спадковими стромальними дистрофіями рогівки. Спостерігалася тенденція до підвищення частоти генотипу $-511 \mathrm{TT}$ гена $I L 1 B$ в групі пацієнтів 3 ерозіями $(3,7 \%)$ порівняно із контролем $(6,7 \%)$. Частота носіїв алеля $-174 \mathrm{C}$ гена IL6 в контрольній групі $(65,9 \%)$ була достовірно $(\mathrm{P}<0,05)$ нижче порівняно з групою пацієнтів 3 ерозіями $(80,5 \%)$. Частота генотипу $-781 T$ тена IL8 була достовірно $(\mathrm{P}<0,05)$ нижчою в групі пацієнтів 3 ерозіями $(10,7 \%)$ порівняно із групою пацієнтів без ерозій (30,8\%) та контролем (25\%). Алель $-174 \mathrm{C}$ гена IL6 може розглядатися як генетичний маркер ризику розвитку ерозій рогівки у пацієнтів зі спадковими стромальними дистрофіями рогівки, в той час як генотип -781 TТ гена $I L 8$, навпаки, асоційований 3 негативним прогнозом розвитку ерозій у таких пацієнтів.

\section{REFERENCES}

1. Waring G., Rodrigues M., Laibson R. Corneal dystrophy: dystrophies of the epithelium, Bowman layer and stromas // Surv. Opthalmol. - 1978. - 23, № 2. P. 97-101.

2. Weidle E. Epitheliale und stromale Hornhautdystrophien // Ophthalmologe. - 1996. - 93, № 6. - P. 754767.

3. Aldave A.J. The genetics of the corneal dystrophies // Dev. Ophthalmol. - 2011. - 48. - P. 51-66.

4. Pampukha V.N., Kravchenko S.A., Tereshchenko F. et al. TGFBI gene mutations in the Ukrainian patients with inherited corneal stromal dystrophies // Genetika. - 2008. - 44, № 10. - P. 1392-1396.

5. Agrawal V.B., Tsai R.J. Corneal epithelial wound healing // Indian J. Ophthalmol. - 2003. - 51, № 1. P. 5-15.

6. Torres P.F., Kijlstra A. The role of cytokines in corneal immunopathology // Ocul. Immunol. Inflam. 2001. - 9, № 1. - P. 9-24.

7. Sotozono C., He J., Matsumoto Y. et al. Cytokine expression in the alkali-burned cornea // Curr. Eye Res. - 1997. - 16, № 7. - P. 670-676.

8. Sotozono $C$. Second injury in the cornea : The role of inflammatory cytokines in corneal damage and repair // Cornea. - 2000. - 19, № 6. - P. S155-S159.

9. Daly A.K., Day C.P., Donaldson P.T. Polymorphisms in immunoregulatory genes: towards individualized immunosuppressive therapy? // Amer. J. Pharmacogenom. - 2002. - 2, № 1. - P. 13-23. 
10. Emonts M., Hazes M.J., Houwing-Duistermaat J.J. et al. Polymorphisms in genes controlling inflammation and tissue repair in rheumatoid arthritis: a case control study // BMC Med. Genet. - 2011. - 12. P. 36.

11. Heinzmann A., Ahlert I., Kurz T. et al. Association study suggests opposite effects of polymorphisms within IL8 on bronchial asthma and respiratory syncytial virus bronchiolitis // J. Allergy Clin. Immunol. 2004. - 114, № 3. - P. 671-676.

12. Rad R., Prinz C., Neu B. et al. Synergistic effect of Helicobacter pylori virulence factors and interleukin-1 polymorphisms for the development of severe histological changes in the gastric mucosa // J. Infect. Dis. - 2003. - 188, № 2. - P. 272-281.

13. Fishman D., Faulds G., Jeffery R. The effect of novel polymorphisms in the interleukin-6 (IL-6) gene on IL-6 transcription and plasma IL-6 levels, and an association with systemic-onset juvenile chronic arthritis // J. Clin. Invest. - 1998. - 102, № 7. P. 1369-1376.

14. Raymond M., Rousset F. GENEPOP (version 1.2): population genetics software for exact tests and ecumenicism // J. Hered. - 1995. - 86. - P. 248-249.

15. Sullivan K.M., Dean A., Soe M.M. OpenEpi: a web- based epidemiologic and statistical calculator for public health // Publ. Health Rep. - 2009. - 124, № 3. - P. 471-474.

16. Matzinger $P$. The danger model: a renewed sense of self // Science. - 2002. - 296. - P. 301-305.

17. Ebihara N., Matsuda A., Nakamura S. et al. Role of the IL-6 classic- and trans-signaling pathways in corneal sterile inflammation and wound healing // Invest. Ophthalmol. Vis. Sci. - 2011. - 52, № 12. P. 8549-8557.

18. Chen H., Wilkins L.M., Aziz N. et al. Single nucleotide polymorphisms in the human interleukin-1B gene affect transcription according to haplotype context // Hum. Mol. Genet. - 2006. - 15, № 4. - P. 519529.

19. Terry C.F., Loukaci V., Green F.R. Cooperative influence of genetic polymorphisms on interleukin- 6 transcriptional regulation // J. Biol. Chem. - 2000. 275, № 24. - P. 18138-18144.

20. Hacking D., Knight J.C., Rockett K. et al. Increased in vivo transcription of an IL-8 haplotype associated with respiratory syncytial virus disease-susceptibility // Gen. Immun. - 2004. - 5, № 4. - P. 274-282.

Received 10.10.12 